Jurnal IImiah Iqra'

2541-2108 [Online] 1693-5705 [Print]

Tersedia online di: http://journal.iain-manado.ac.id/index.php/JII

\title{
Peran Kepala Madrasah Dalam Pencegahan Krisis Akhlak Siswa di Madrasah Ibtidaiyah Swasta Mata Air Kota Padang
}

\author{
Ahmad Putra \\ Pascasarjana UIN Sunan Kalijaga, Yogyakarta \\ Pratamaahmad954@gmail.com
}

\begin{abstract}
Abstrak
Berkembangnya zaman ke era digital turut memengaruhi akhlak dan perilaku setiap manusia, termasuk siswa. Pada akhirnya, penting sekali bila perbaikan akhlak menjadi hal utama dalam menjadikan siswa tetap konsisten dalam menjalankan perannya sebagai pelajar. Kepala madrasah memiliki wewenang dan tanggung jawab dalam menyelesaikan berbagai problematika yang dialami siswa sehingga dapat meminimalisasi krisis akhlak yang ditampilkan siswa. Tujuan penelitian ini ialah mengetahui bagaimana peran kepala madrasah dalam mencegah krisis akhlak di sekolah. Metode penelitian yang digunakan ialah kualitatif. Lokasi penelitian di MIS Mata Air Kota Padang. Subjek penelitian ini ialah kepala sekolah, siswa, dan guru. Hasil penelitian ini ialah terdapat beberapa bentuk penyimpangan yang dilakukan oleh siswa seperti bolos belajar, merokok di wc, tidak menghargai guru, tidak sopan ketika berbicara kepada guru, sering berkata kotor ketika berkomunikasi dengan teman sebaya, kedapatan membawa handphone, bergaya yang tidak pantas dan tidak patuh kepada kedua orangtua. Peran yang dilakukan oleh kepala madrasah terkait pencegahan krisis akhlak siswa ialah memberikan hukuman, menasehati, mengajarkan cara menjadi siswa yang baik, melalui cerita-cerita motivasi dan berdiskusi.
\end{abstract}

Kata kunci: Kepala Madrasah; Krisis Akhlak

\begin{abstract}
The development of the era into the digital era also influenced the morals and behavior of every human being, including students. In the end, it is very important if moral improvement becomes the main thing in making students stay consistent in carrying out their role as students. The principal has an authority and responsibility in resolving various polemics experienced by students so as to minimize the moral crisis displayed by students. The purpose of this study is to find out how the role of
\end{abstract}


the headmaster in preventing a moral crisis in schools. The research method used is qualitative. The location of the study was at MIS Mata Air Padang City. The subjects of this study were the principal, students, and teachers. The results of this study are that there are some forms of deviation committed by students such as skipping study, smoking in the toilet, not respecting the teacher, not polite when talking to the teacher, often saying dirty when communicating with peers, found carrying a cellphone, inappropriate style and disobedient to both parents. The role carried out by the headmaster of madrasa related to preventing the moral crisis is to provide punishment, advise, teach how to be a good student, through motivational stories and discussions.

Keywords: Principal of Madrasa; Crisis of Morals

\section{Pendahuluan}

Keberadaan madrasah tentunya menjadi sangat penting dalam dunia pendidikan di negeri ini. Hal tersebut dikarenakan madrasah berperan sentral dalam menjadikan manusia menjadi individu yang bermoral, bernilai, berkarakter dan menjadikan individu yang mampu dalam mengubah diri kepada arah yang lebih berakhlak benar (Srimulyani, 2007). Kehadiran madrasah tentunya menjadi sangat penting dalam aspek perubahan, yang mana saat sekarang semuanya serba maju dan berubah, sebut saja salah satunya akhlak siswa/pelajar. Semakin hari dan seiring berkembangnya zaman, akhlak dan perangai siswapun juga berubah serta semakin memperlihat perubahan yang sangat signifikan, sehingga telah saatnyalah peran madrasah kembali memberikan penyegaran kepada semua individu. Salah satu yang berperan penting dalam hal ini tentunya kehadiran kepala madrasah/sekolah (Rahman, 2014).

Keberadaan kepala madrasah tentunya menjadi faktor penting dalam memberikan perubahan di madrasah yang tengah dipimpinnya. Berubah atau tidaknya madrasah tentunya ada di tangannya dan dengan amanah yang berada di tangannya juga menjadi sebuah pilihan apakah bisa memberikan sebuah perkembangan atau tidak. Salah satu tugas penting kepala madrasah ialah dengan memanfaatkan sumber daya madrasah secara maksimal, seperti memperbaiki kinerja guru, pegawai di madrasah, siswa, sarana dan bagaimana hubungan dengan masyarakat sekitar madrasah, tentunya semua itu menjadi aspek yang sangat penting sehingga benar-benar memberikan kontribusi dalam perkembangan madrasah melalui kepala madrasah (Ibrahim Bafadal, 2000).

Menjalankan peran dan tugas sebagai kepala madrasah, tentunya tengah menjalankan sebuah kepemimpinan yang dipercayakan kepada dirinya. Mengingat 
pentingnya seorang pemimpin, maka perlu diingat bahwa fungsi pemimpin dalam dunia pendidikan ialah bagaimana dengan wewenang yang dimiliki mampu menciptakan dan mewujudkan situasi proses pembelajaran yang efektif, siswapun dapat belajar dengan baik. Inilah merupakan upaya dalam menciptakan siswa yang sejahtera, membentuk siswa yang bertanggung jawab, serta siswa mampu menjadi semakin berkembang akan pengetahuan (Baharun, 2017). Kepala Madrasah menjalankan organisasi yang dipimpinnya bukan hanya sekedar pelaksana suatu kebijakan nasional atau preservasi nilai-nilai yang ada dalam suatu masyarakat, tetapi pendidikan itu sendiri dilihat sebagai salah satu kekuatan sosial yang turut memberi bentuk, corak dan arah pada kehidupan masyarakat masa depan (Ellong \& Pawero, 2018).

Berbicara mengenai kepala madrasah, tentunya juga ikut membicarakan perihal pendidikan Islam dalam kehidupan manusia. Abdurrahman Wahid pernah mengatakan bahwa perjalanan panjang yang manusia lalui di kehidupan ini ialah sejauhmana kehidupan yang dilaluinya dapat memberikan makna dan warna tersendiri serta bisa memperlihatkan eksistensinya sebagai makhluk ciptaan Tuhan dan mampu menyiapkan pegangan untuk kehidupan selanjutnya melalui bekal yang didapatkan dalam kehidupan dunia ini (Syam, 2005).

Menjadi kepala madrasah tentunya tengah menjalani sebuah kepimpinan yang telah dipercayakan untuk dirinya sehingga ia benar-benar diharuskan bisa berusaha dan berperan sebagai orang yang dapat memberika pengaruh baik, bisa mengkoordinir dengan tepat, bisa membimbing, baik membimbing pengajar dan yang terpenting sekali yaitu bisa membimbing serta mengarahkan siswa yang ada di madrasah. Tujuannya agar perencanaan yang telah dibuat oleh kepala madrasah benar-benar berjalan dengan baik dan sesuai dengan yang direncanakan dari awal (Soetopo \& Soemanto, 2002).

Pada satu sisi, kepala madrasah tidak hanya berupaya menjalankan tugas dari sisi pembelajaran saja, akan tetapi juga membentuk siswa yang baik akhlaknya, benar perbuatannya, membentuk kejujuran dan memahami benar dan buruknya suatu perbuatan. Peran kepala madrasah dan guru sebagai tenaga pendidik dalam sebuah institusi pendidikan sangat strategis. Kepala madrasah juga sebagai key person dalam mengelola individu yang ada di madrasah, dan juga mempunyai peranan yang besar dalam menciptakan keberhasilan madrasah. Pada akhirnya budaya keharmonisan dan keberhasilan dapat selalu terjalankan dengan baik, tepat dan berorientasi pada keberhasilan bersama (Peterson \& Deal, 2011). 
Peran kepala madrasah menjadi sentral, karena kehadirannya diharapkan memberikan warna baru dalam dunia pendidikan, cenderung mengalami krisis akhlak siswa yang disaat sekarang dapat dikatakan cenderung mengalami krisis. Akibatnya banyak siswa yang tidak lagi memiliki akhlak yang baik, jauh dari harapan sebagai seorang siswa dan mudah terperangkap dalam kenakalan. Akan tetapi, yang menjadi titik serius dalam penelitian ini ialah perlunya kepala madrasah mencegah krisis akhlak yang tengah dialami siswa saat ini terkhusus di MIS Mata Air Kota Padang.

MIS Mata Air terletak di Jalan Sutan Syahrir Kelurahan Mata Air Kecamatan Padang Selatan Kota Padang Provinsi Sumatera Barat. Sekolah ini terakreditasi B, berstatus swasta, memiliki 415 siswa, 15 guru, 6 kelas, 125 Pelajaran dan 2 kegiatan ekstrakulikuler. Madrasah ini setara dengan tingkat SD yang terletak di daerah yang cukup strategis dan padat penduduk. Berdasarkan wawancara baik dengan kepala sekolah, jajaran guru maupun masyarakat yang ada di sekitar sekolah, diketahui bahwa siswa yang ada di madrasah mengalami krisis akhlak, dibuktikan dengan seringnya siswa berkata-kata kotor ketika berbincang-bincang dengan teman sebaya, berpakaian tidak pantas (memperlihatkan aurat dan ketat), memperolokolok guru, merokok di wc, tidak menghargai guru. Beberapa siswi juga sering terlihat keluar malam sambil bertemu dengan geng laki-laki dan tidak memakai jilbab ketika keluar malam.

Melihat berbagai fenomena terkait dengan krisis akhlak yang terjadi pada siswa MIS Mata Air Kota Padang, menjadi tugas dan tantangan kepala madrasah dalam mencari cara atau solusi dalam mencegah serta memberantas krisis akhlak pada siswa. Di titik ini peran kepala madrasah menjadi penting dengan ikut serta dalam menciptakan ahlak siswa yang benar, mulia, dan memberikan kebermanfaatan bagi diri siswa sendiri, serta tidak terlibat pada berbagai bentuk kenakalan yang tentunya merugikan. Menarik bila kita melihat peran kepala madrasah dalam menghadapi problem yang terjadi, sehingga dalam penelitian ini yang menjadi titik serius yang ingin diketahui yaitu bagaimana peran kepala madrasah dalam mencegah krisis akhlak di MIS Mata Air Kota Padang, bentuk krisis akhlak yang terjadi pada siswa dan faktor penyebabnya.

\section{Kajian Teori}

Peran merupakan sebuah proses dalam menggerakkan jabatan. Jika seseorang tersebut melakukan sebuah tugas atau pekerjaan yang telah menjadi tanggung jawabnya, seseorang itu mesti melaksanakan peran. Maka dengan itu, antara jabatan dengan peranan tidak bisa dipisahkan, saling berkaitan dan 
berhubungan antara satu dengan yang lain (Soerjono Soekanto, 2009). Peran juga berarti lakon yang dimainkan oleh seorang pemain, dalam pendidikan tentunya peran yang menjalankan tingkah laku tertentu yang menjadi sebuah ciri khas orang yang menjalankan pekerjaan atau sebuah jabatan, atau dengan kata lain peran artinya suatu bagian pemilik pimpinan yang pertama (Afrida, 2012).

\section{Kepala Madrasah dan Peran Pentingnya}

Memiliki amanah sebagai kepala madrasah, tentunya diikat dengan sebuah tanggung jawab yang tidak ringan. la memiliki peran yang mesti dijalankan dengan baik demi mencapai tujuan hakiki dari sebuah madrasah yang telah ditetapkan. Kerja sama dengan semua lapisan menjadi cara terbaik dalam mencapai keberhasilan dalam bertugas, sehingga kepala madrasah benar-benar menjadi sebuah organisasi yang kompleks, dan menjalankan tanggung jawab dengan maksimal demi mencapai keproduktivitasan madrasah yang lebih baik (Salim, 2013).

Kepala madrasah yang baik ialah kepala madrasah yang mempunyai taktik atau startegi, dan cara-cara yang bagus dalam mengupayakan majunya madrasah yang tengah dipimpinnya. Dengan adanya strategi tentunya semua program yang dirancang dapat terlaksana dengan tepat dan pastinya akan terwujud keberhasilan dalam menjalankan sebuah tanggung jawab. Sudah saatnya seorang kepala madrasah mempersiapkan strategi yang jitu, tepat dan menjamin terbentuknya program-program yang memberikan kontribusi bagi madrasah, guru dan siswa (Hadi, Djailani, \& Ibrahim, 2014).

Kepala madrasah merupakan pendorong dalam upaya perkembangan dan usaha untuk memajukan sekolah dalam meningkatkan keberhasilan siswa. Semua itu akan tercapai tentunya ada hal-hal yang harus dilakukan, dan kepala madrasah harus benar-benar menjalankan perannya sebagai pemimpin dengan baik serta benar. Jika telah dijalankan dengan benar dan tepat, maka pendidikan yang dirancang dengan sedemikian cara akan dapat terwujud dengan maksimal, tentunya karena bantuan dari pendidik/pengajar yang ada di linkungan madrasah (Fitrah, 2017).

Kepala madrasah seharusnya dapat berperan aktif dalam menjalankan tugas dan fungsinya sebagai seorang pemimpin. la memiliki tugas yang penting karena bisa mengkoordinasikan, menggerakkan dan menyelaraskan sumber daya pendidikan yang tersedia. Menurut Sagala, kepala madrasah/sekolah adalah 
seseorang yang diberi tugas dan amanah untuk mengelola sekolah agar mencapi sebuah tujuan yang terbaik (Ruhiyat, 2017). Menjadi sosok yang sentral dalam tugas yang diemban, kepala madrasah diharapkan memanfaatkan potensi sumber daya manusia yang dimilikinya melalui motivasi, dorongan semangat, dan membantu guru agar dapat menjadi pendidik yang cakap dalam mengajar siswa. Upaya tersebut tentunya menjadikan pengajaran kepada siswa menjadi lebih tepat, dan siswapun bertambah pengetahuannya (Jalal \& Supriadi, 2008).

Terkait dengan kesuksesan kepala madrasah, Mulyasa mengemukakan beberapa kunci sukses kepemimpinan kepala madrasah dalam menjalankan tugas, diantara : visi dan misi yang utuh (jelas), bertanggung jawab dalam menjalankan amanah, memiliki nilai-nilai keteladanan dalam diri, bisa bekerja sama dengan baik bersama staf yang ada di madrasah, mau berdiskusi dan mendengarkan masukan dari orang lain, berusaha maksimal memberikan pelayanan kepada madrasah dan siswa, mengatur manajemen madrasah secara professional, pandai dalam menjalankan gaya kepemimpinan dan menggunakan wewenang dengan tepat (Mulyasa, 2013). Selain itu, kesusksesan guru dalam menerapkan nilai-nilai akhlak kepada siswa merupakan wujudk kesuksesan kepala madrasah. Hal ini sebagaimana salah satu tujuan pendidikan Islam yaitu menjadikan manusia yang beriman dan bertakwa kepada Allah swt, serta berakhlak mulia (Pawero, 2017)

Dalam menjalankan perannya sebagai kepala madrasah, ada beberapa peran yang harus dijalankan, diantaranya :

1. Sebagai educator, sebagai kepala madrasah harus memahami kompetensi guru agar menjadi pendidik yang mampu meningkatkan kinerja dan kualitas pembelajaran di sekolah, sehingga siswapun dapat merespon dengan baik terhadap apa yang disampaikan oleh gurunya. Salah satu tokoh yang memberikan pendapatnya terkait dengan educator ini ialah Mulyana, dimana beliau mengatakan bahwa sebagai seorang educator, kepala madrasah perlu menekankan pembinaan terhadap mental siswa, moralnya, pembinaan terkait dengan fisik serta terkait dengan artistic siswa (Mulyasa, 2006).

2. Sebagai manajer, kepala madrasah memiliki tugas sebagai pengelola institusi. Maka, kepala madrasah harus melaksanakan kerja sama yang baik dengan semua lapasan dan melibatkan tenaga pendidik yang ada di madrasah terbangun kualitas pendidikan yang solid antar guru dalam memberikan pengajaran. 
3. Sebagai supervisor, kepala sekolah melakukan pembinaan secara terstruktur agar semua guru dan pegawai yang ada mampu melaksanakan pekerjaannya dengan maksimal dan berjuang keras. Sehingga dalam tugas ini, kepala sekolah menjalankan peran yang baik terhadap semua pendidik agar selalu siap memberikan pembelajaran yang berkualitas kepada siswa. Dalam hal ini, kepala madrasah selalu melakukan pengawasan terhadap ketercapaian semua tujuan madrasah, yaitu menciptakan budaya dan lingkungan belajar yang positif, sehingga potensi siswa benar-benar tersalurkan dengan baik (National Education Association, 2008).

4. Sebagai administrator, kepala sekolah memiliki tanggung jawab terkait dengan kelancaran pelaksanaan pendidikan yang dijalankan dan berhubungan dengan perencanaan madrasah, menyusun organisasi madrasah, bertindak selaku coordinator dan pengarah bagi semua tenaga pendidik yang ada (Purwanto, 2005).

5. Sebagai leader, kepala madrasah menjadi seorang pemimpin yang berperan menjadi pengendali dari madrasah yang dipimpinnya, maka kepala madrasah harus mempunyai kualifikasi yang pada akhirnya dapat dipercaya, jujur dalam bertindak dan memahami keadaan guru. kepemimpinan yang dimaksud dalam hal ini ialah bagaimana kepala madrasah dapat mempengaruhi orangorang yang ada disekitarnya dan lingkungan, sehingga sama-sama dapat berkoordinasi, saling bekerja sama demi tujuan madrasah dan siswa (Fatoni, 2017).

6. Sebagai inovator, kepala madrasah memiliki kemampuan dalam memberikan pembaharuan bagi semua aspek di madrasah, baik itu berhubungan dengan cara pengajaran yang tepat, BK dan kegiatan ekstrakulikuler.

7. Sebagai motivator, kepala madrasah juga memiliki tugas untuk mengatur ruang kantor agar tetap kondusif dalam bekerja, aman dalam proses BK dan lancer dalam hal pratikum serta menciptakan suasana madrasah yang aman, tenteram dan nyaman.

8. Kepala madrasah harus menciptakan hubungan kerja yang harmonis dengan sesame guru, karyawan, saling menghargai dan membangun hubungan kekeluargaan yang baik.

9. Menjalin hubungan yang baik dengan sesama madrasah dan tentunya dengan lingkungan madrasah agar terbangun keharmonisan demi kebaikan bersama (Ellong \& Pawero, 2018). 
Beberapa peran yang telah dijelaskan di atas, berkaitan erat dengan upaya dalam membantu memperbaiki krisis akhlak yang tengah terjadi pada siswa di madarah. Peran kepemimpinan yang melekat pada tugas kepala madrasah tentunya sangat berkontribusi dalam menciptakan hubungan antar kepala madrasah dengan guru, siswa serta lingkungan yang harmonis, sehingga dapat membentuk akhlak yang baik pada siswa.

Disamping beberapa peran yang ada pada wewenang seorang kepala madrasah, juga terdapat beberapa kompetensi yang harus dimiliki oleh kepala madrasah, diantaranya:

1. Kompetensi Kepribadian Ini terkait dengan jiwa seorang pemimpin, yaitu mesti berkahlak yang baik, loyalitas, semangat dalam bekerja dan menikmati amanah yang telah dipercayakan pada dirinya.

2. Kompetensi Manajerial

Terkait dengan perencanaan perkembangan sekolah, seperti upaya dalam mengembangkan organisasi sekolah/madrasah, mengelola sumber daya yang ada di sekolah, menjadikan sekolah yang kondusif, memanfaatkan ilmu pengetahuan yang ada, dan mengelola sarana prasarana dengan maksimal.

3. Kompetensi Kewirausahaan

Terkait dengan daya juang dalam mengembangkan perkembangan madrasah yang lebih baik, melaksanakan tugas dengan tujuan yang memberikan kebermanfaatan buat semua jajaran yang ada di madrasah dan menjadikan sarana yang ada sebagai cara menambah keilmuan bagi semua siswa yang ada di madrasah.

4. Kompetensi Supervisi

Terkait dengan rencana-rencana sebuah program akademik dalam rangka meningkatkan profesionalisme guru.

5. Kompetensi Sosial

Terkait dengan upaya dalam menggerakkan secara bersama-sama agar semua orang yang ada di dalam sekolah/madrasah sama-sama memberikan kontribusi yang baik buat sekolah dan semua siswa. Ini dapat menjadikan kepala madrasah benar-benar berupaya agar siswa mampu mempraktekkan akhlak yang baik kepada lingkungan serta orang-orang yang ada di sekitarnya. 
Dari penjelasan tersebut dapat dipahami bahwa tugas dan tanggung jawab seorang kepala madrasah sangat berat dan membutuhkan sebuah kerja sama yang efektif dengan semua lapisan yang ada di madrasah, termasuk dengan lingkungan. Semua itu akan dapat memberikan kontribusi bagi perbaikan akhlak siswa agar krisis yang tengah dialami oleh anak-anak sekarang dapat diminimalisasi dengan peran efektif kepala madrasah.

Semua peran penting yang dijalankan oleh kepala madrasah, juga ikut ditambahkan oleh Mulyasa terkait dengan beberapa kriteria yang harus dimiliki oleh seorang pemimpin dalam dunia pendidikan, diantaranya :

1. Mampu menjadikan guru agar menjadi pendidik yang memberikan pengajaran secara baik kepada siswa.

2. Bagus dalam mengatur waktu dalam proses pengajaran, sehingga sesuai dengan apa yang diharapkan.

3. Harus bisa membangun hubungan baik dengan orang-orang yang ada di lingkungan, baik itu di lingkungan sekolah maupun di luar sekolah.

4. Mampu menjadi seorang pemimpin yang bisa didengarkan oleh lingkungan.

5. Mampu bekerja sama dengan baik secara bersama-sama dengan tujuan yang sama.

6. Sama-sama berusaha demi kebaikan madrasah dan kebaikan siswa tentunya (Mulyasa, 2002).

Menjadi pemimpin pendidikan Islam juga harus senantiasa mengedepankan pengelolaan pendidikan yang berorientasi kepada pemberdayaan sekolah serta peningkatan mutu pendidikan secara berkelanjutan, terarah dan menyeluruh (Daeng Pawero, 2018)

Menjadi pemimpin di dunia pendidikan, terdapat beberapa faktor yang mempengaruhi agar semua itu bisa terjalankan, diantaranya yaitu :

1. Kepribadian kepala madrasah harus mencerminkan seorang pendidikan yang benar-benar dapat di contoh oleh semua orang.

2. Perilaku yang sesuai, sehingga semua orang yang ada di madrasah benarbenar patuh dan menerima semua perintah.

3. Berkarakter yang baik.

4. Rekan kerja yang mau bekerja sama dengan baik dan efektif. 
5. Semua pendidik yang ada di madrasah benar-benar memiliki tekad yang sama. Yaitu harapan dalam memperbaiki berbagai lini yang perlu diperbaiki (Fatah, 2006).

\section{Krisis Akhlak}

Peranan akhlak sangatlah penting dalam upaya pembangunan tatanan kehidupan bangsa. Selain itu, akhlak juga menjadi penentu dalam kaitannya dengan aspek keagamaan, moral dan pengamalan gaya hidup yang benar, seperti rohani dan emosi. Hanya saja, dengan berkembangnya zaman dan cara hidup yang begitu kompleks, menjadikan akhlak manusia yang dalam hal ini siswa/pelajar menjadi runtuh serta mengalami krisis akhlak yang serius. Akibatnya keruntuhan akhlak yang dialami generasi bangsa saat sekarang menandakan ada yang salah dan pola didikan yang tidak tepat, akibatnya dimana-mana sering kita melihat para generasi muda yang tidak lagi dapat dikatakan berakhlak, baik melalui sikap maupun perbuatan (Bahori, Madya, Ismail, Khazarita, \& Khalib, 2017).

Terjadinya krisis akhlak pada siswa, bukanlah tanpa sebab. Menurut Townsend dan Butterworth mengatakan bahwa ada beberapa hal yang menentukan terwujudnya pendidikan yang bermutu, di antaranya : keefektifan gaya kepemimpinan kepala madrasah, rasa tanggung jawab guru dan staf di madrasah, efektif atau tidaknya proses belajar di madrasah, kurikulum madrasah yang relefan, visi misi madrasah yang jelas dan akurat, iklim madrasah yang kondusif dan nyaman serta keterlibatan orang tua dan masyarakat secara saling berkesinambungan antara satu sama lain.

Pendapat lain mengatakan, bahwa faktor yang menyebabkan para generasi muda mengalami krisis akhlak ialah faktor keluarga, artinya ada permasalahan yang tengah melanda keluarga seperti terjadinya perceraian sehingga anak terlantar dan tidak terurus, orangtua sibuk bekerja termasuk bekerja ke luar negeri, sehingga anak tidak mendapatkan perhatian dan pengawasan penuh, factor lingkungan juga ikut memengaruhi si anak dimana lingkungan memengaruhi keadaan social dan pribadi anak dalam bertindak serta bersikap. Begitulah yang terjadi saat ini, dimana krisis akhlak tengah melanda banyak generasi muda negeri, salah satunya ialah siswa/pelajar yang ada di madrasah/sekolah (Ramdhun, 2006).

Ketika melihat akhlak sebagian siswa yang memperlihatkan ketidakbenaran, maka kepala madrasah harus mampu membangun interaksi, baik interaksi antar 
individu maupun kelompok di lingkungan madrasah. Dengan demikian, kepala madrasah harus mempunyai kecerdasan emosional sehingga dapat mengetahui emosi diri, mengelola diri orang lain dan mampu membinanya dengan baik (Aprilana, Kristiawan, \& Hafulyon, 2016).

\section{Metode}

Jenis penelitian yang digunakan dalam penelitian ini adalah penelitian kualitatif dengan cara kerja prosedur penelitian yang menghasilkan data deskriptif berupa kata kata tertulis/lisan dari orang/perilaku yang diamati dan memaparkan seperti apa adanya tanpa persepsi peneliti (Moleong, 1995). Informan dalam penelitian ini adalah Kepala Madrasah, Siswa dan Wali Kelas. Teknik pengumpulan data dalam penelitian ini adalah observasi dan wawancara kepada para informan.

\section{Hasil Dan Pembahasan}

\section{Upaya kepala Madrasah dalam Mencegah Krisis Akhlak Siswa MIS Mata Air Kota Padang \\ Berdasarkan hasil penelitian yang dilakukan, diketahui bahwa kepala} madrasah telah melakukan berbagai upaya dan cara dalam mencegah krisis akhlak pada siswa. Peran kepala madrasah sangat ditunggu-tunggu dengan harapan dapat memperbaiki krisis akhlak yang ada di MIS Mata Air. Kepala madrasah yang merupakan pemimpin pada tugas yang diembannya tersebut menjadi garda terdepan penggerak untuk memberikan kemajuan dan perubahan bagi semua lini, akhlak siswa salah satunya serta akan selalu menjadi kebutuhan seiring perubahan zaman (Fauzi, 2017).

Adapun upaya yang dilakukan oleh kepala madrasah dalam mencegah krisis akhlak pada siswa ialah dengan pemberian nasehat ringan, menegur siswa yang bermasalah dan yang menariknya yaitu kepala madrasah memberikan motivasi kepada siswa dengan menceritakan kisah-kisah atau materi keagamaan, seperti mengenai kisah-kisah anak yang durhaka, cara mendapatkan masa depan yang cerah, cara menjadi anak yang shaleh dan disayangi oleh guru, dan bahaya yang akan diterima kelak di akhirat bila sebagai anak tidak melakukan kebaikan.

Cara yang seperti ini rutin diberikan oleh kepala madrasah ketika ada siswa yang bermasalah dan ketika kegiatan kultum di hari jumat. Keahlian dan keilmuan 
kepala madrasah yang bukan dari keagamaan, menjadi menarik karena secara tidak langsung memberikan tantangan bagi kepala madrasah memberikan pengajaran dan upaya yang bersifat keagamaan kepada siswa. Sehingga, memberikan sinyal bahwa walaupun kepala madrasah tidak dari keahlian atau keilmuan agama, akan tetapi tetap mampu berupaya membantu pencegahan krisis akhlak pada siswa melalui motivasi keagamaan.

\section{Bentuk Krisis Akhlak yang Dialami Siswa MIS Mata Air Kota Padang}

Berdasarkan hasil penelitian yang dilakukan, ditemukan beberapa bentuk krisis akhlak pada siswa yang cukup mengkwatirkan. Bentuk krisis akhlak pada siswa berupa bolos belajar, merokok di wc, tidak menghargai guru di kelas, tidak sopan ketika berbicara kepada guru, sering berkata kotor ketika berkomunikasi dengan teman sebaya, ketika berbicara kasar kepada kakak kelas, siswa mengikuti gaya barat (memakai cat rambut), mengolok-olok guru dan beberapa siswa ada yang kedapatan mengambil barang teman.

Beberapa siswa juga kedapatan berbicara dengan nada tinggi ke guru dan jauh dari kata sopan santun. Fenomena krisis akhlak yang terjadi ini tentunya tidak bisa dianggap biasa saja, karena jika ini tidak diselesaikan dengan cepat maka akan mempengaruhi diri siswa di masa yang akan datang. Maka dengan itu, peran kepala madrasah sangat sentral, sehingga membutuhkan kerja sama antara kepala madrasah dengan jajaran guru dalam memperbaiki akhlak siswa.

\section{Faktor-Faktor Penyebab Krisis Akhlak Siswa MIS Mata Air Kota Padang}

Berdasarkan hasil penelitian yang dilakukan, ditemukan beberapa factorfaktor penyebab krisis akhlak siswa MIS Mata Air Kota Padang. Faktor pendukung terjadinya krisis akhlak pada siswa ialah lingkungan yang tidak memberikan perlindungan kepada anak, hubungan pertemanan yang tidak bagus, ajakan teman sebaya yang menyimpang seperti sering diajak keluar malam dan merokok, beberapa siswa ada yang terlantar karena orangtua mereka bercerai, pengaruh media social serta keinginan mengikuti tren kekinian. Beberapa siswa juga dititipkan di panti social, sayangnya pengawasan dari pengurus panti tidak ketat sehingga siswa yang tinggal disana sering bersikap seenaknya, seperti keluar dari panti tanpa izin dan berpakaian ketat.

Kesulitan dalam melakukan upaya merubah akhlak buruk tersebut juga dapat dilihat pada faktor orang tua. Perhatian orangtua yang tidak maksimal kepada anak sehingga anak mengikuti arus kehidupan seenak hatinya serta kurangnya didikan 
orangtua perihal pengenalan ilmu keagamaan kepada anak yang mengakibatkan anak minim dengan pengetahuan agama. Hal ini kemudian menyebabkan kepala madrasah belum mampu secara maksimal bertindak tegas serta menerapkan langkah yang tepat dalam mencegah akhlak yang buruk pada diri siswa.

\section{Simpulan}

Peran kepala madrasah sangatlah penting dalam menyelesaikan permasalahan krisis akhlak yang tengah melandah siswa di MIS Mata Air Kota Padang. Kepala madrasah telah melakukan berbagai upaya dalam meminimalisasi kenakalan yang ada pada siswa, sehingga dengan tugas dan tanggung jawab yang ada, kepala madrasah telah berperan penting dan berkontribusi pada terhadap akhlak siswa. Adapun cara yang dilakukann kepala madrasah dalam menuntaskan permasalahan krisis akhlak siswa yaitu selain memberikan nasehat, juga diberikan motivasi keagamaan, seperti cara-cara menjadi anak yang shaleh dan baik, menjadi siswa yang dicintai guru-guru dan yang terpenting sekali yaitu siswa diberikan motivasi yang berkaitan dengan masa depannya kelak, sehingga siswa dapat benarbenar fokus dalam belajar dari usia sekolah dasar.

\section{Referensi}

Afrida. (2012). Peran Guru Pendidikan Agama Islam dalam Meningkatkan Prestasi Belajar Siswa tentang Pelajaran Agama di SD Limus Nunggal 02 Cileungsi. Jakarta: FITK UIN Jakarta.

Aprilana, E. R., Kristiawan, M., \& Hafulyon. (2016). Kepemimpinan Kepala Madrasah Dalam Mewujudkan Pembelajaran Efektif Di Madrasah Ibtidaiyyah Rahmah El Yunusiyyah Diniyyah Puteri Padang Panjang. ELEMENTARY, 4(1), 1-22.

Baharun, H. (2017). Peningkatan Kompetensi Guru Melalui Sistem Kepemimpinan Kepala Madrasah. At-Tajdid : Jurnal Ilmu Tarbiyah, 6(1), 1-26.

Bahori, A., Madya, Ismail, S. Z., Khazarita, N., \& Khalib, N. M. (2017). Keperluan Hukuman Alternatif Terhadap Penyelesaian Krisis Akhlak di Malaysia; Analisis Pendekatan Undang-Undang Syariah. In Prosiding Persidangan Antarabangsa Kelestarian Insan (pp. 1-10).

Daeng Pawero, A. M. V. (2018). Analisis Kritis Kebijakan Kurikulum Antara KBK, KTSP, dan K-13. Jurnal Ilmiah Iqra', 12(1), 42. https://doi.org/10.30984/jii.v12i1.889 
Ellong, T. D. E., \& Pawero, A. M. D. (2018). Islamic Education Management for Millenial Generation; Quality and Competitivaness. In The 1st Annual Conference on Islamic Education Management (ACIEM). Yogyakarta: Fakultas Ilmu Tarbiyah dan Keguruan UIN Sunan Kalijaga.

Fatah, N. (2006). Landasan Manajemen Pendidikan. Bandung: Remaja Rosdakarya.

Fatoni, M. (2017). Peran Kepala Madrasah Dalam Meningkatkan Mutu Guru Di Mts Nurul Falah Talok Kresek Kabupaten Tangerang. Tarbawi, 3(2), 68-82.

Fauzi, A. (2017). Kepemimpinan Kepala Madrasah Dalam Mengembangkan Lembaga Pendidikan Islam. Nidhomul Haq, 2(2), 53-64.

Fitrah, M. (2017). Peran Kepala Sekolah Dalam Meningkatkan Mutu Pendidikan. Jurnal Penjaminan Mutu, 31-42.

Hadi, M., Djailani, A., \& Ibrahim, S. (2014). Strategi Kepala Madrasah Dalam Meningkatkan Mutu Pendidikan Pada Min Buengcala Kecamatan Kuta Baro Kab Aceh Besar. Jurnal Administrasi Pendidikan Pascasarjana Universitas Syiah Kuala, 4(2), 40-48.

Jalal, F., \& Supriadi, D. (2008). Reformasi Pendidikan dalam Konteks Otonomi Daerah. Jakarta: Bumi Aksara.

Moleong, L. J. (1995). Metodologi Penelitian Kualitatif. Bandung: Rosdakarya.

Mulyasa. (2006). Menjadi Kepala Sekolah Profesional. Bandung: Remaja Rosda Karya.

Mulyasa, E. (2002). Manajemen Berbasis Sekolah: Konsep, Strategi, dan Implementasi. Bandung: PT Remaja Rosdakarya.

Mulyasa, E. (2013). Manajemen Dan Kepemimpinan Kepala Madrasah. Jakarta: Bumi Aksara.

National Education Association. (2008). Changing Role of School Leadership. Retrieved February 20, 2020, from http:/www.nea.org/assets/ docs/PBo9_Leadershipo8.pdf

Pawero, A. M. (2017). Analisis Kritis Kebijakan Standar Kompetensi Lulusan (SKL) Dan Standar Isi Kurikulum Pendidikan Agama Islam. Journal of Islamic Education Policy, 2(2). https://doi.org/10.30984/j.v2i2.700

Peterson, K. D., \& Deal, T. E. (2011). The Shaping School Culture Feldbook. Hoboken.

Purwanto, N. (2005). Administrasi dan Supervisi Pendidikan. Bandung: Remaja Rosda Karya.

Rahman, B. (2014). Kepemimpinan Multidimensi Kepala Madrasah Dari Perspektif Guru. ANALISIS: Jurnal Studi Keislaman, 14(2), 431-453.

Ramdhun, A. B. (2006). Ranjau Ranjau Pergaulan Bebas. Jakarta: Sanabil Pustaka. 
Ruhiyat, M. Y. (2017). Pengaruh Kepemimpinan Kepala Madrasah Dan Supervisi Pengawas Madrasah Terhadap Kinerja Guru Untuk Mewujudkan Mutu Pendidikan Di Madrasah. Jurnal Pendidikan Universitas Garut, 11(1), 26-37.

Salim, A. (2013). Peran Kepala Madrasah Wanita Dalam Pengelolaan Penerimaan Siswa Baru Di Maarif Brajan Banjararum Kalibawang Kulon Progo. Literasi, 4(1), 71-88.

Soerjono Soekanto. (2009). Sosiologi Suatu Pengantar. Jakarta: Rajawali Press.

Soetopo, H., \& Soemanto, W. (2002). Pengantar Operasional Administrasi Pendidikan. Surabaya: Usaha Nasional.

Srimulyani, E. (2007). Muslim Women and Education in Indonesia: The pondok pesantren experience. Asia Pacifc Journal of Education, 27(1), 85-99.

Syam, Y. H. (2005). Mendidik Anak ala Muhammad. Yogyakarta: Penerbit Sketsa. 